\title{
Chemical Mixtures and Environmental Effects: A Pilot Study to Assess Ecological Exposure and Effects in Streams
}

\author{
By Herbert T. Buxton, ${ }^{1}$ Timothy J. Reilly, ${ }^{1}$ Kathryn M. Kuivila, ${ }^{1}$ Dana W. Kolpin, ${ }^{1}$ Paul M. Bradley, ${ }^{1}$ \\ Daniel L. Villeneuve, ${ }^{2}$ and Marc A. Mills ${ }^{2}$
}

\begin{abstract}
What chemicals occur together in our streams and at what concentrations? How do land-use and chemical-use patterns influence the complex chemical mixtures in streams across the Nation? How do these chemicals enter streams and do they persist? Can exposure to chemical mixtures result in unanticipated, adverse health effects in fish and other aquatic organisms? Could people be exposed to these chemical mixtures? This document presents some of the challenges associated with chemical mixtures in streams and describes an interagency (U.S. Geological Survey and U.S. Environmental Protection Agency), field-based investigation designed to help answer these and other questions and to provide information to guide future research.
\end{abstract}

\section{Contaminant Mixtures in Surface Waters}

Streams and lakes accumulate chemicals from many different human activities across the landscape (fig. 1). Watersheds collect water from precipitation that runs off the land surface, carrying with it chemicals from urban and residential areas (streets, sidewalks, parking lots, lawns, and gardens); crop lands treated with pesticides, manures, and

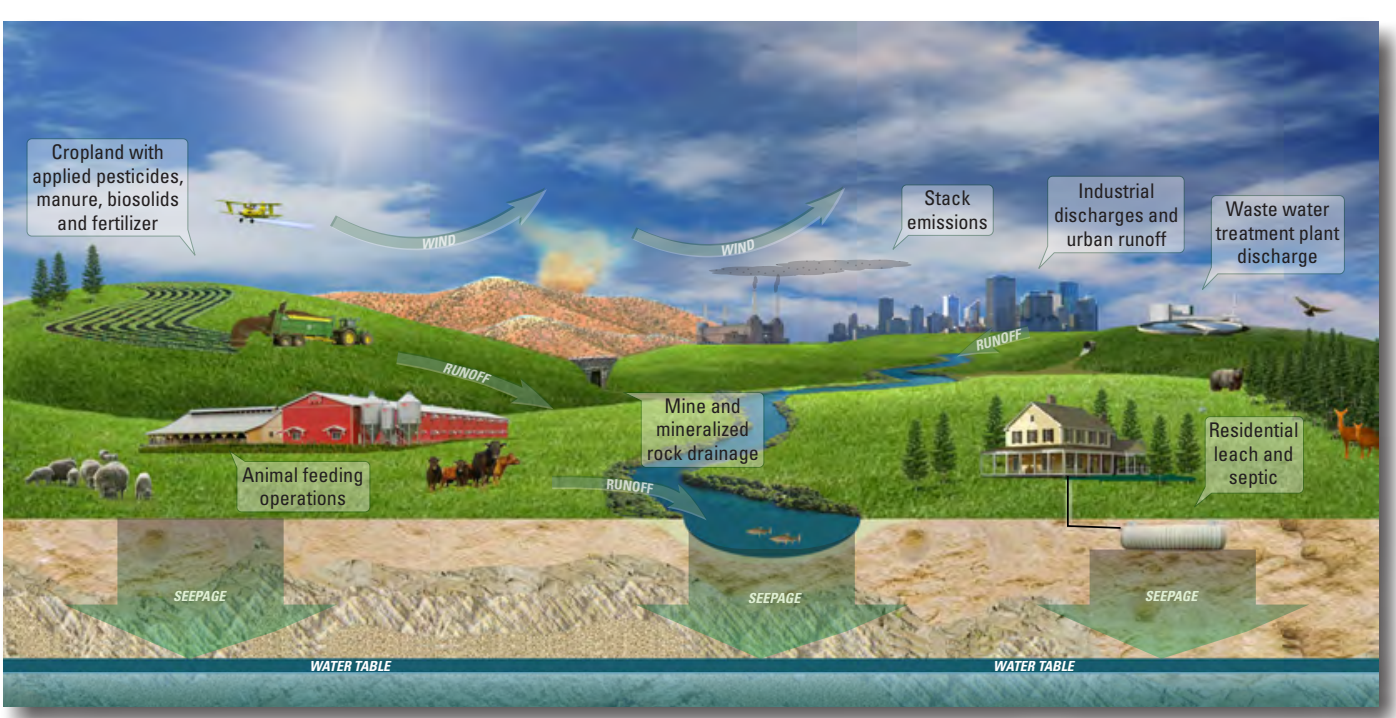

Figure 1. Contaminant sources and principal pathways to the environment. From Bright and others (2013).

\footnotetext{
${ }^{1}$ U.S. Geological Survey.

${ }^{2}$ U.S. Environmental Protection Agency.
}

other organic and inorganic fertilizers; pastures and animalproduction facilities; and lands where energy and mineral resources are extracted. Municipal, commercial and domestic wastewater-treatment systems, industries, and landfills can discharge their wastewaters directly to streams, and although the wastewater typically is treated, current treatment technologies are not designed to remove all chemicals. Groundwater, which discharges to streams and accounts for much of streamflow during dry seasons, also can carry contaminants from spills, leaks, septic systems, and land-applied chemicals that infiltrate

to the water table as well as naturally occurring chemicals that leach from aquifer material. Even chemicals from smokestacks, automobiles, and other emissions to the atmosphere can make their way into streams. As a result, surface waters can have complex mixtures of natural and anthropogenic chemicals that include pesticides, pharmaceuticals, household chemicals, and a wide range of chemicals produced as waste byproducts of commercial and industrial activities. 


\section{The Challenge of Chemical Mixtures}

Assessment and management of the risks of exposure to complex chemical mixtures in streams are priorities for human and environmental health organizations around the world, including the U.S. Environmental Protection Agency (Doyle and others, 2014), the U.S. National Institute of Environmental Health Sciences (Carlin and others, 2013), the U.S. Geological Survey (Bright and others, 2013), the European Commission (European Commission, 2015), and the World Health Organization (World Health Organization, 2015). The current lack of information on the composition and variability of environmental mixtures and a limited understanding of the combined effects are fundamental obstacles to timely identification and prevention of adverse human and ecological effects of exposure to chemical mixtures.

The number of chemicals registered for use in the United States is immense and increasing rapidly. In comparison, assessment of health risks and subsequent development of environmental regulations have progressed slowly, been conducted largely on a chemical-by-chemical basis, and focused primarily on mortality, acute toxicity, and carcinogenicity. As a result, the vast majority of these chemicals remain untested for their biological mode(s) of action and toxicity, and very few mixtures have been assessed for potential chemical interactions and their combined effect. To address this knowledge gap, high throughput testing and other automated methods are being developed for more efficient evaluation of the biological activity and toxicity of chemicals (National Research Council, 2007; Collins and others, 2008). However, even robust chemical characterization of environmental chemical mixtures has been found to explain only a small fraction of the observed biological response to exposure (Tang and others, 2014).

\section{Environmental Health Effects of Chemical Mixtures}

\section{Predicting the Combined Effects of Chemical Mixtures}

Testing for the health effects of all potential chemical mixtures is not feasible. Therefore, multiple approaches have been developed for using the results of chemical-specific testing to assess the combined effects of chemical mixtures. Chemicals often are assumed to act additively in terms of their concentration, dose, potency, or biological response to exposure. These approaches are challenged by changes in response with exposure time, the biological interaction of chemicals within an organism, and complex dose-response relations including the effects thresholds below which individual chemicals do not demonstrate effects. Adverse health effects have been demonstrated from exposure to multiple chemicals at low concentrations, which individually would not cause harm (Brian and others, 2007; Smith and others, 2013; Kortenkamp,
2014). Chemical interactions can result in impacts that are greater than (synergistic) or less than (antagonistic) those predicted by additive approaches. An everyday example of an unanticipated chemical interaction is the need to avoid consuming grapefruit when taking specific medications due to its potential to amplify pharmacological effects in some patients (Kane and Lipsky, 2000). Examples of environmental contaminants known to interact synergistically or antagonistically include polycyclic aromatic hydrocarbons (Schneider and others, 2002), pesticides (Belden and Lydy, 2006; Laetz and others, 2009; Christen and others, 2014; Chen and others, 2015), metals (Norwood and others, 2003), pesticides and metals (Chen and others, 2015), antibiotics (Gonzalez-Pleiter and others, 2013), pharmaceuticals with similar (Cleuvers, 2004) and different modes of action (Pomati and others, 2008), pharmaceuticals and metals (Aslop and Wood, 2013), pharmaceuticals and synthetic musks (Schnell and others, 2009), polycyclic aromatic hydrocarbons and metals (Wang and others, 2013), and more diverse chemical mixtures (Boltes and others, 2012; Orton and others, 2014).

\section{Health Outcomes}

Adverse human and environmental health outcomes other than acute toxicity and mortality may occur in streams even at low contaminant concentrations due to the complexity of chemical mixtures and associated chemical modes of action. Modes of action may include carcinogenicity, genotoxicity, mutagenicity, toxicity modulation, endocrine disruption, and selection of microbial antibiotic resistance.

As an example, many of the chemicals that enter our streams can disrupt the endocrine systems of aquatic organisms. Hormones, secreted by an organism's endocrine system, play a major role in biological function and metabolic stability. Endocrine disrupting chemicals can interfere with natural hormone signaling in exposed organisms, resulting in altered growth, sexual development and function, neurological development, metabolism, and stress response (DiamantiKandarakis and others, 2009). Estrogenically active contaminants can interfere with natural estrogen binding, affecting sexual differentiation and development, among other things. Estrogenic contaminants in streams may include estrogens produced naturally in animals and subsequently excreted (biogenic estrogens), estrogenic chemicals produced in plants (phytoestrogens), synthetic pharmaceutical estrogens (ovulation inhibitors or estrogen supplements), and estrogen mimics (a wide range of chemicals with industrial and commercial uses including some pesticides, flame retardants, surfactants, and products in plastics). In one study, severe population declines were documented in fish in a Canadian lake dosed with a single compound, 17- $\alpha$ ethinyl estradiol, an active ingredient in human birth control pills (Kidd and others, 2007). Fish and other aquatic organisms that inhabit contaminated streams are often exposed to many endocrine-active chemicals, not just one. Because endocrine disruption effects 
often do not conform to established, dose-response relations, these chemicals pose a serious challenge to traditional toxicological risk assessment practices (Fuhrman and others, 2015).

The adverse effects of antimicrobial resistance on human health and the potential significance of both clinical and natural environments in resistance selection are also widely acknowledged (Wellington and others, 2013; Martinez, 2014). The ability of microorganisms to resist antibiotic and antimicrobial agents can be affected by multiple chemical exposures and can be transferred between organisms (Kummerer, 2009). Chemicals with the potential to select resistance genes and resistant microbial populations include metals (Baker-Austin and others, 2006), quaternary ammonium compounds (Gaze and others, 2005), biocides (Sanchez and others, 2005), and herbicides (Kurenbach and others, 2015). Resistance to an individual antibiotic can be further affected by other antibiotics and metals acting on the same genetic target or on different targets on the same genetic element (Baker-Austin and others, 2006). Common antibiotic pathways to the environment include chemical use and disposal in animal agriculture, in healthcare facilities, and in the home.

The combined adverse health effects of exposure to multiple chemicals and of physical insults from other stressors that affect different organs or biological functions, as well as indirect effects on complex ecological relations such as host-pathogen interactions, are critical challenges (Sexton and Hattis, 2007; Lokke and others, 2013; Hadrup, 2014).

\section{A Pilot Study}

The U.S. Geological Survey (USGS) and the U.S. Environmental Protection Agency (EPA) are collaborating to provide new information on environmental chemical mixtures in United States streams. The objective of the study is to characterize chemical mixtures and biological activity in surface waters that are affected by diverse chemical sources. The study is intended to provide fieldbased information for the prioritization and design of future research on environmental chemical mixtures. The study represents the most comprehensive assessment of the chemical composition and biological activity of contaminant mixtures in surface waters ever performed in the United States.

\section{Pilot Study Approach}

\section{Site Selection}

Data from more than a thousand stream sites from previous USGS studies of contaminants of emerging environmental concern were used to select 38 stream sites spanning 24 States and Puerto Rico (fig. 2; table 1). Thirty-four stream sites were selected because they have highly developed watersheds with a wide range of contaminant sources; the remaining four stream sites were selected as undeveloped reference sites.

Sites vary widely in upstream drainage area, ranging from 4.6 square miles $\left(\mathrm{mi}^{2}\right)$ for a small reference site on Penn Swamp Branch in the Pinelands of New Jersey to 6,265 $\mathrm{mi}^{2}$ for the Trinity River, an arid southwestern stream in Texas (table 1). Most of the study watersheds cover areas less than $100 \mathrm{mi}^{2}$ (fig. 3A). Population density also varies widely (fig. $3 B$ ), ranging from zero (Swiftcurrent Creek, a reference site near Many Glacier, Montana) to almost 3,000 people per $\mathrm{mi}^{2}$ (Rush Creek near Arlington, Texas).

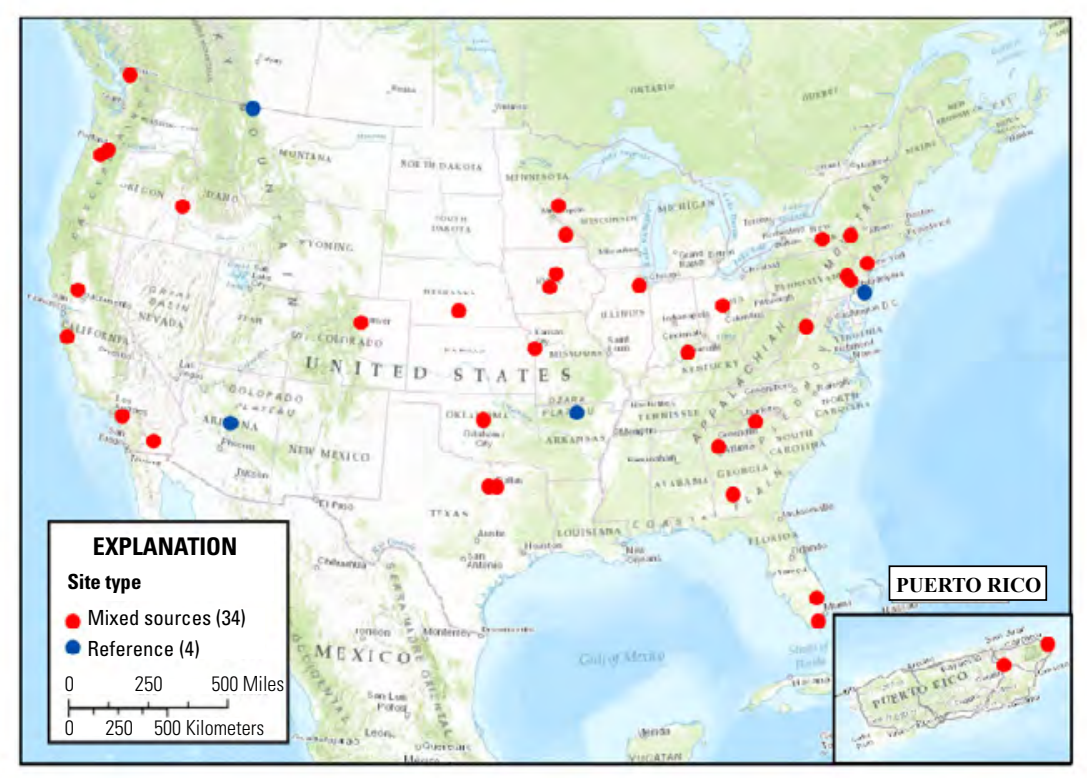

Figure 2. Stream sampling locations. Thirty-four of 38 stream sites (red markers) have a wide range of contaminant sources within their watersheds; the remaining four stream sites (blue markers) were selected as reference sites because their watersheds are minimally affected by contaminant sources and their biological communities are considered to be unaffected or minimally affected by development. 
Table 1. Stream sampling sites, location, watershed drainage area, and date sampled.

[Latitude and longitude in decimal units, referenced to the North American Datum of 1983 (NAD 83); drainage area in square miles]

\begin{tabular}{|c|c|c|c|c|c|c|}
\hline Stream name & Location & Station number & Latitude & Longitude & $\begin{array}{l}\text { Drainage } \\
\text { area }\end{array}$ & Sample date \\
\hline \multicolumn{7}{|c|}{ Developed watersheds } \\
\hline Abrams Creek & near Oakfield, Georgia & 2350524 & 31.7187847 & -83.98851469 & 79.58 & July 23, 2013 \\
\hline Blue River & at Kansas City, Missouri & 06893500 & 38.957 & -94.5588889 & 184.19 & February 11, 2014 \\
\hline C-111 Canal & near Homestead, Florida & 252414080333200 & 25.40428063 & -80.5586705 & 51.04 & April 9, 2013 \\
\hline $\begin{array}{l}\text { Chicago Sanitary and Ship } \\
\text { Canal }\end{array}$ & at Lockport, Illinois & 05537000 & 41.57027778 & -88.0794444 & 749.34 & February 11, 2014 \\
\hline Chisholm Creek & at Edmond, Oklahoma & 07159735 & 35.72560669 & -97.5272639 & 38.78 & November 28, 2012 \\
\hline Deep Creek & at Highway 224, Oregon & 452340122251000 & 45.39429 & -122.42064 & 48.98 & January 13, 2014 \\
\hline $\begin{array}{l}\text { East Branch Perkiomen } \\
\text { Creek }\end{array}$ & $\begin{array}{l}\text { near Derstines, } \\
\text { Pennsylvania }\end{array}$ & 01472705 & 40.35402778 & -75.31327778 & 29.35 & January 14, 2014 \\
\hline Enoree River & at Pelham, South Carolina & 02160326 & 34.85650727 & -82.22622468 & 84.80 & May 19, 2014 \\
\hline Fall Creek & near Ithaca, New York & 423400 & 42.4533333 & -76.47277778 & 126.35 & June 9, 2014 \\
\hline Fishtrap Creek & near Lynden, Washington & 12211900 & 49.00261838 & -122.4073816 & 16.45 & December 10, 2013 \\
\hline Fourmile Creek & $\begin{array}{l}\text { downstream of the } \\
\text { Ankeny WWTP outfall, } \\
\text { Iowa }\end{array}$ & 05485605 & 41.7173771 & -93.5701332 & 60.94 & November 19, 2012 \\
\hline Hawksbill Creek & $\begin{array}{l}\text { at Route 648, Springfield, } \\
\text { Virginia }\end{array}$ & 01630540 & 38.70817319 & -78.4563966 & 68.52 & April 15, 2014 \\
\hline Hillsboro Canal & $\begin{array}{l}\text { at S-6, near Shawano, } \\
\text { Florida }\end{array}$ & 02281200 & 26.4720184 & -80.4458857 & 311.34 & March 12, 2013 \\
\hline Hite Creek & $\begin{array}{l}\text { at Sleepy Hollow Road } \\
\text { near Prospect, } \\
\text { Kentucky }\end{array}$ & 382054085332600 & 38.34833 & -85.55722 & 5.54 & May 20, 2014 \\
\hline Hohokus Brook & $\begin{array}{l}\text { at Ho-Ho-Kus, New } \\
\text { Jersey }\end{array}$ & 01391100 & 40.95527778 & -74.1005556 & 20.47 & November 28, 2012 \\
\hline Jordan Creek & $\begin{array}{l}\text { at the mouth, at Allen- } \\
\text { town, Pennsylvania }\end{array}$ & 01452040 & 40.6018 & -75.46208889 & 82.32 & June 17, 2013 \\
\hline Mill Creek & near Bellepoint, Ohio & 03220000 & 40.24839457 & -83.1738026 & 177.93 & June 4, 2013 \\
\hline New River & $\begin{array}{l}\text { near Westmorland, Cali- } \\
\text { fornia }\end{array}$ & 10255550 & 33.10476565 & -115.6644382 & $1,471.12$ & March 5, 2013 \\
\hline North Dry Creek & $\begin{array}{l}\text { South of Kearney, } \\
\text { Nebraska }\end{array}$ & 06770195 & 40.6411236 & -99.1159223 & 78.74 & June 10, 2013 \\
\hline Rio Bairoa & at the mouth, Puerto Rico & 50055410 & 18.26106496 & -66.0187762 & 7.68 & March 19, 2013 \\
\hline Rio Fajardo & $\begin{array}{l}\text { downstream of the Fa- } \\
\text { jardo WWTP outfall, } \\
\text { Puerto Rico }\end{array}$ & 181932065383501 & 18.31297222 & -65.6536111 & 20.38 & March 25, 2013 \\
\hline Rush Ck & $\begin{array}{l}\text { at Hwy } 303 \text { near Arling- } \\
\text { ton, Texas }\end{array}$ & 324305097101900 & 32.71794 & -97.17201 & 28.89 & May 13, 2013 \\
\hline
\end{tabular}


Table 1. Stream sampling sites, location, watershed drainage area, and date sampled._-Continued

[Latitude and longitude in decimal units, referenced to the North American Datum of 1983 (NAD 83); drainage area in square miles]

\begin{tabular}{|c|c|c|c|c|c|c|}
\hline Stream name & Location & Station number & Latitude & Longitude & $\begin{array}{l}\text { Drainage } \\
\text { area }\end{array}$ & Sample date \\
\hline \multicolumn{7}{|c|}{ Developed watersheds } \\
\hline Sand Run Gulch & $\begin{array}{l}\text { at Highway } 95 \text { crossing } \\
\text { near Parma, Idaho }\end{array}$ & 13210360 & 43.7640501 & -116.9120956 & 79.49 & June 18, 2013 \\
\hline Santa Ana River & $\begin{array}{l}\text { downstream of Prado } \\
\text { Dam, California }\end{array}$ & 11074000 & 33.88334875 & -117.6453296 & $2,261.44$ & March 25, 2014 \\
\hline Sope Creek & near Marietta, Georgia & 02335870 & 33.95388889 & -84.4433333 & 30.81 & April 16, 2013 \\
\hline South Fork Iowa River & $\begin{array}{l}\text { near New Providence, } \\
\text { Iowa }\end{array}$ & 05451210 & 42.31498375 & -93.1524252 & 266.39 & May 20, 2013 \\
\hline South Fork Zumbro River & $\begin{array}{l}\text { downstream of WWTP } \\
\text { near Rochester, } \\
\text { Minnesota }\end{array}$ & 05373005 & 44.0738534 & -92.46767819 & 312.00 & December 5, 2012 \\
\hline South Platte River & near Commerce, Colorado & 39484710457700 & 39.8130418 & -104.9524794 & $4,082.21$ & December 11, 2012 \\
\hline Sunrise River Tributary & $\begin{array}{l}\text { near Lindstrom, } \\
\text { Minnesota }\end{array}$ & 05340041 & 45.4076111 & -92.8805889 & 6.59 & December 4, 2012 \\
\hline Sycamore Slough & $\begin{array}{l}\text { at County Line Road near } \\
\text { Dunnigan, California }\end{array}$ & 385531121532001 & 38.92527778 & -121.8888889 & 64.30 & June 18, 2013 \\
\hline Tembladero Slough & at Castroville, California & 364554121453401 & 36.765 & -121.7594444 & 153.97 & March 3, 2014 \\
\hline Trinity River & $\begin{array}{l}\text { downstream of Dallas, } \\
\text { Texas }\end{array}$ & 08057410 & 32.70763139 & -96.7358319 & $6,264.63$ & December 4, 2012 \\
\hline $\begin{array}{l}\text { West Branch Delaware } \\
\text { River }\end{array}$ & at Hobart, New York & 01421640 & 42.3436111 & -74.72 & 48.22 & November 19, 2012 \\
\hline Zollner Creek & $\begin{array}{l}\text { near Mount Angel, } \\
\text { Oregon }\end{array}$ & 14201300 & 45.10039816 & -122.8217596 & 15.90 & May 19, 2014 \\
\hline \multicolumn{7}{|c|}{ Reference Sites } \\
\hline North Sylamore Creek & near Fifty Six, Arkansas & 07060710 & 35.99166667 & -92.2138889 & 58.7 & January 7, 2014 \\
\hline Penn Swamp Branch & near Batsto, New Jersey & 01409480 & 39.68416667 & -74.65027778 & 4.6 & December 10, 2012 \\
\hline Swiftcurrent Creek & $\begin{array}{l}\text { upstream of Swiftcurrent } \\
\text { Lake at Many Glacier, } \\
\text { Montana }\end{array}$ & 05014300 & 48.7954444 & -113.6805833 & 15.4 & August 28, 2013 \\
\hline West Clear Creek & $\begin{array}{l}\text { near Camp Verde, } \\
\text { Arizona }\end{array}$ & 09505800 & 34.53863606 & -111.6940356 & 241 & January 15, 2014 \\
\hline
\end{tabular}



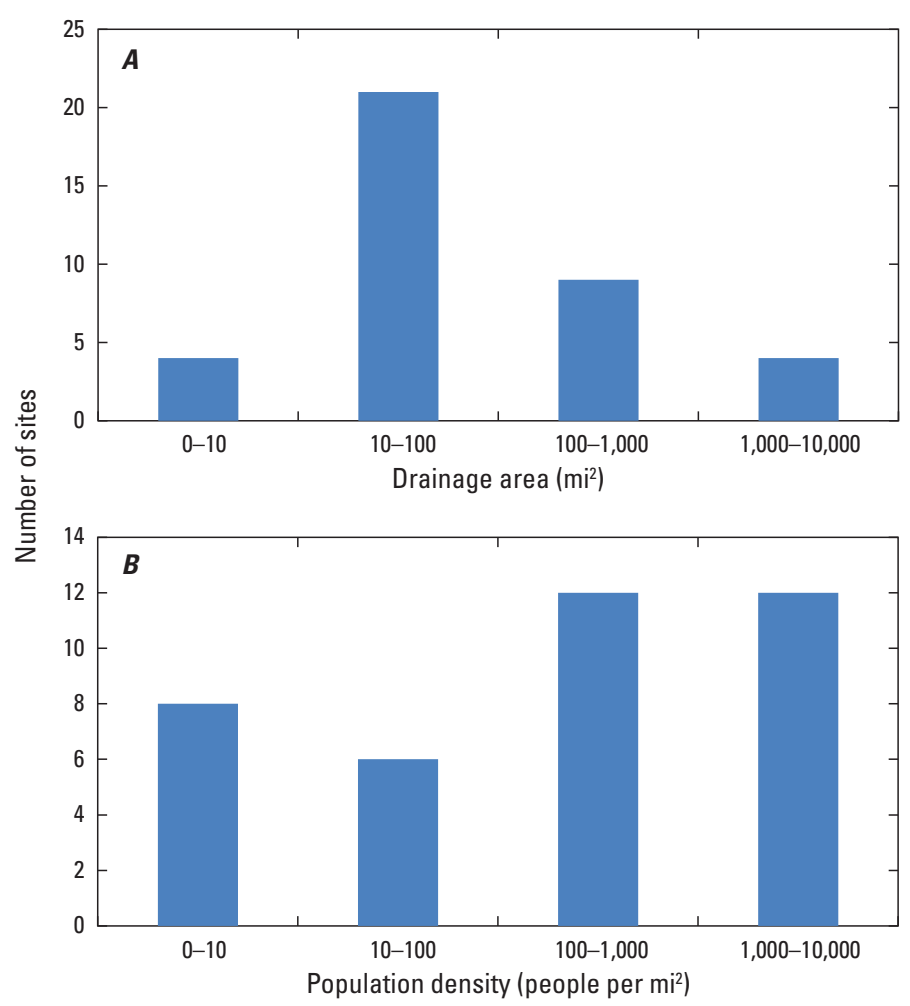

Figure 3. Watershed characteristics of sampled stream sites. $A$, Distribution of drainage areas in square miles. $B$, Distribution of watershed population densities in people per square mile.

Some watersheds are characterized almost entirely by agricultural land (fig. 4A). Mixed urban/agricultural land use is common, with urban land (fig. 4B) generally covering less area than agricultural land. The Hite Creek site in Kentucky (fig. 5) is an example of a developed watershed affected by highly varied contaminant sources. The $5.5 \mathrm{mi}^{2}$ watershed is approximately 52 percent urban land and 10 percent agricultural land. It has a population density of about 2,323 people per $\mathrm{mi}^{2}$ and includes a National Pollutant Discharge Elimination System (NPDES) major discharger.

The watersheds of the four stream reference sites are largely undeveloped, minimally affected by contaminant sources, and considered to have minimally disturbed fish and aquatic macro-invertebrate communities. For example, the $15.4 \mathrm{mi}^{2}$ Swiftcurrent Creek watershed in Montana (fig. 6) has no urban land, 0.1 percent agricultural land, and no major NPDES dischargers. The population density of the watershed is less than 1 person per $\mathrm{mi}^{2}$.

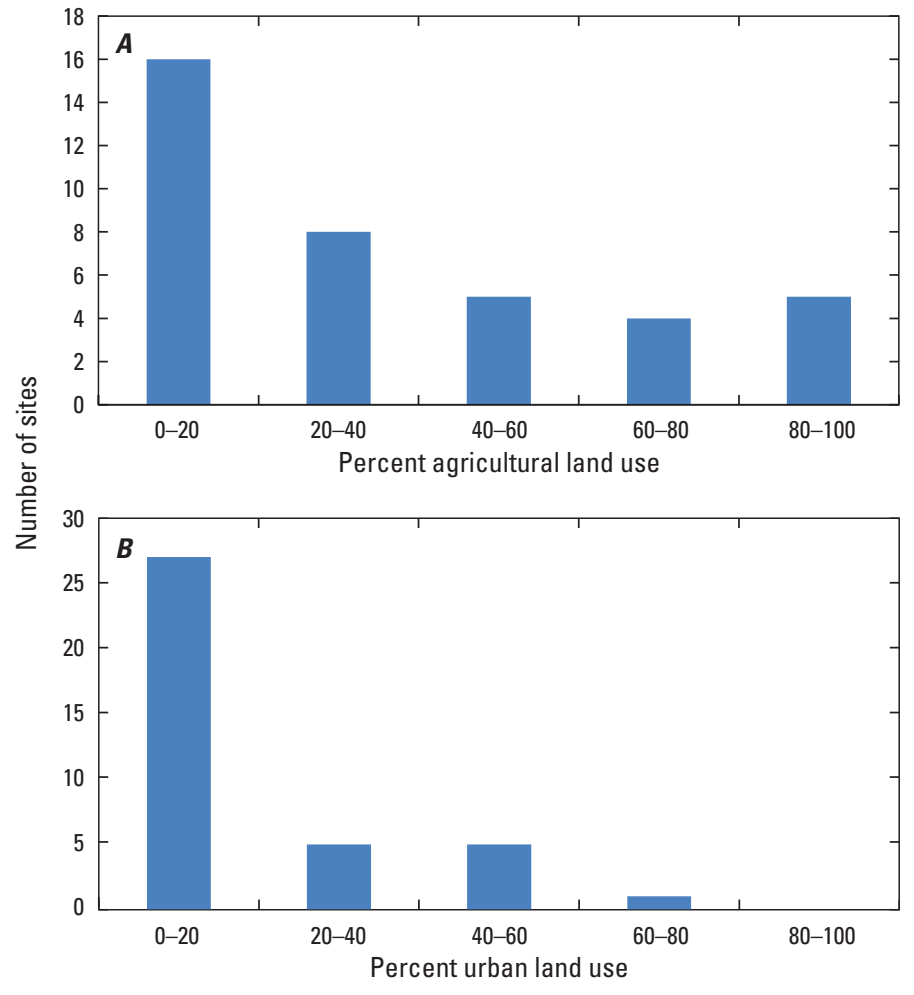

Figure 4. Distribution of $A$, Agricultural and $B$, Urban land use as a percentage of total drainage area for streamsite watersheds. (2011 National Land Cover Database [conterminous United States, http://www.mrlc.gov/nlcd2011.php]; Puerto Rico 2001 National Land Cover Database [Puerto Rico, http://www.mrlc.gov/nlcd01_data.php])

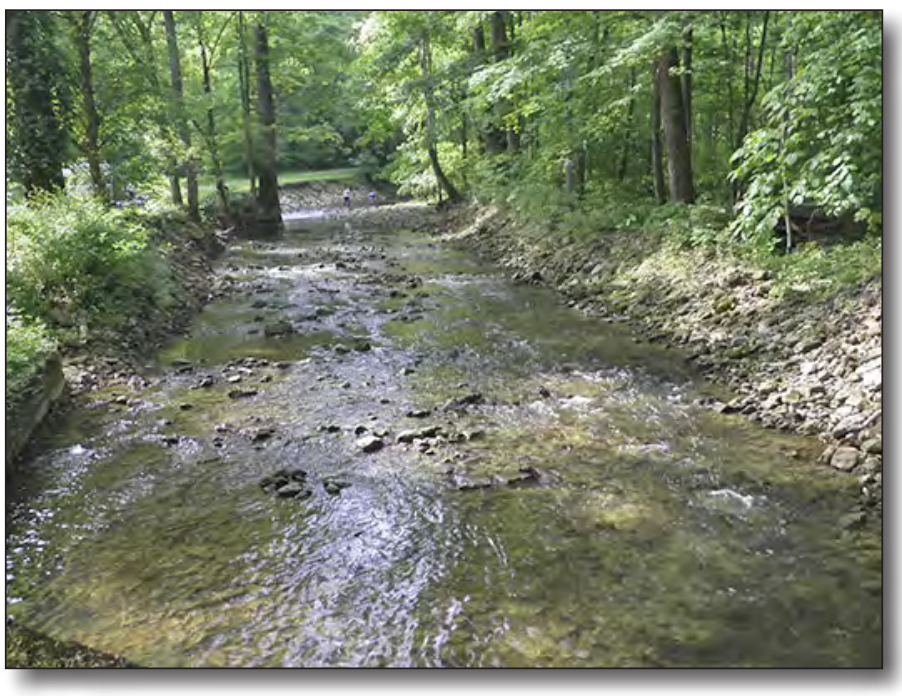

Figure 5. Hite Creek Kentucky, looking upstream at the sampling location. Photograph by Angela Crain, USGS. 


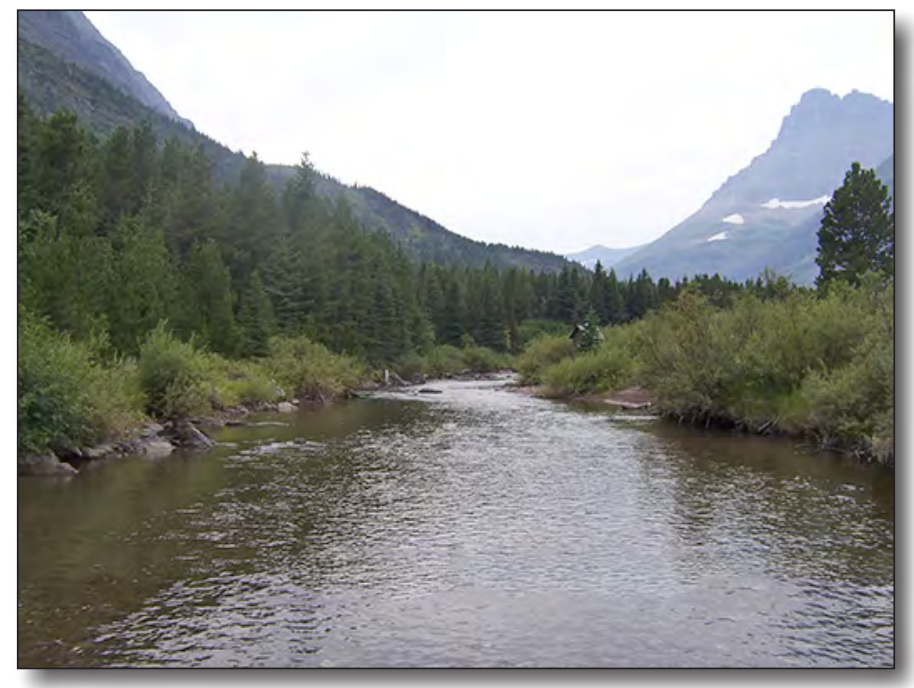

Figure 6. Swiftcurrent Creek, Montana, looking upstream at the sampling location. Photograph by Hannah Nilges, USGS.

\section{Sample Collection and Analysis}

Water samples were collected once from each stream from December 2012 to June 2014. Samples taken from the center of flow at each stream were collected by USGS staff using established trace-level protocols (Shelton, 1994; Wilde, 2004a; Wilde and others, 2004b; Hladik and others, 2009). Composite water samples were homogenized and decanted into the specified container or collected within the specified container as appropriate. Water samples were kept at 3 degrees Celsius $\left({ }^{\circ} \mathrm{C}\right)$ while in the field and more than 60 sample bottles were shipped overnight to USGS and EPA national laboratories for analysis (fig. 7).

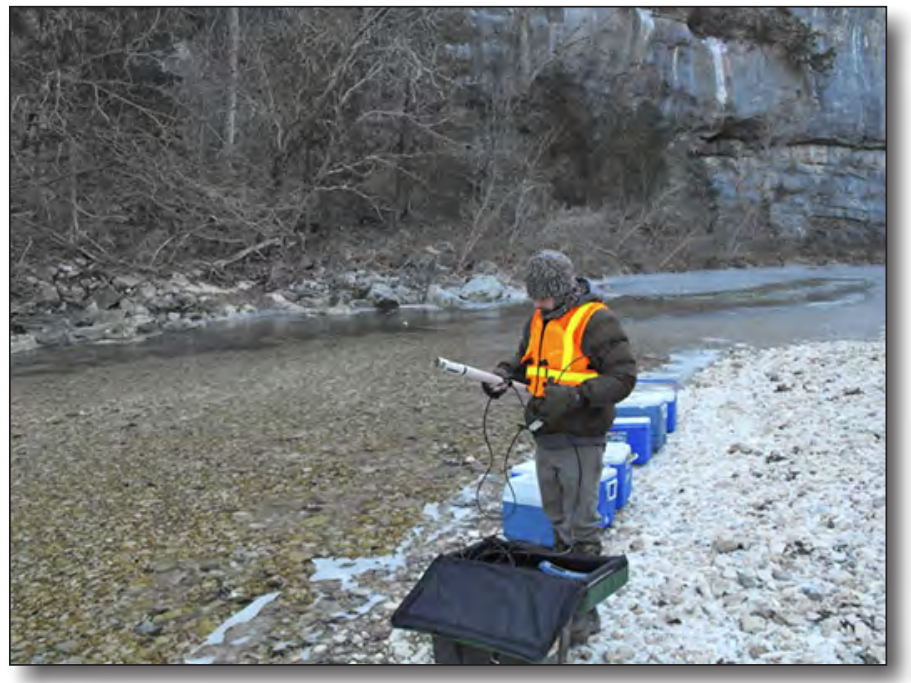

Figure 7. U.S. Geological Survey scientist collecting water samples and measuring water field properties at North Sylamore Creek, Arkansas, on January 7, 2014, a study reference site. Photograph by J. Tyler Mays, USGS.
Stream water samples were tested using (1) sensitive and specific direct analysis for more than 700 organic and inorganic chemicals and physical properties (table 2), (2) environmental diagnostics for identification of unknown chemical contaminants using Gas Chromatography-Mass Spectrometry and Liquid Chromatography-Time of Flight Mass Spectrometry, and (3) a variety of bioassays to evaluate biological activity and toxicity, including hormonal activity, carcinogenicity, and mutagenicity (table 3 ). In addition, a subset of 8 ambient water extracts from sites selected from a range of environmental settings were screened for approximately 80 different biological activities using the Attagene, Inc., subset of ToxCast ${ }^{\mathrm{TM}}$ assays (U.S. Environmental Protection Agency, 2015). The chemical analytes measured include anthropogenic and naturally occurring chemicals as well as associated metabolites and environmental transformation byproducts.

\begin{tabular}{|c|c|}
\hline 339 & Pesticides and transformation byproducts \\
\hline 160 & Pharmaceuticals and metabolites \\
\hline 32 & Antibiotics and metabolites \\
\hline 38 & Biogenic and synthetic hormones and conjugates \\
\hline 40 & Volatile organic compounds \\
\hline 25 & Disinfectants and byproducts \\
\hline 22 & Metals \\
\hline 17 & Flame retardants \\
\hline 17 & Perfluorocarbons (PFCs) \\
\hline 11 & Surfactants \\
\hline 10 & Phytoestrogens and plant sterols \\
\hline 9 & Fragrances \\
\hline 9 & Nutrient species, and \\
\hline Othe & ndustrial chemicals \\
\hline
\end{tabular}

Table 3. Bioassays used to measure biological activity and toxicity of stream water samples.

Estrogen agonist and antagonist assays

Androgen assays

Glucocorticoid assays

Steroidogenesis (estrogen and testosterone production) assays

DNA binding transcription factor activity assays

Carcinogenicity and mutagenicity assays

DNA damage assays

Gene expression and metabolite profiling 


\section{Pilot Study Significance}

The results of this pilot study will (1) document the mixtures and associated concentrations of chemicals found in stream waters, (2) help identify potential ecological and human exposures, (3) guide prioritization of toxicological studies of chemical mixtures, (4) provide insight into potential biological interaction of multiple contaminants, (5) help relate bioassay screening approaches to environmental chemical characterization in support of new monitoring strategies, and (6) provide a base of data for models to predict chemical mixtures in watersheds affected by diverse land-use and chemicaluse patterns.

This pilot study also provides the basis for evaluating the feasibility of future field-based research on environmental chemical mixtures. The information about these sites can be used to design more detailed studies that address additional environmental media (sediment and tissue), multiple concurrent exposure pathways, temporal variations in chemical mixtures resulting from the timing of chemical-use practices and environmental transformation, acute and chronic effects of exposure to mixtures, and adverse health effects from varied chemical and physical insults at the organism, population, and community levels.

\section{Integrated Approach to Chemical Mixtures Assessment, Source Identification, and Mitigation}

Understanding and mitigating the human and ecological health risks associated with chemical- and land-use practices require knowledge of environmental chemical mixtures,
Environmental bioassays allow for rapid assessment of environmental samples and can be used as cost-effective screening tools to identify susceptible environmental settings, the biological activity exhibited by environmental waters, and the associated adverse health outcomes on aquatic organisms. Field testing using test organisms (such as caged fish studies) can play an important role in documenting adverse health effects. Environmental chemical analyses permit spatial and temporal characterization of actual environmental chemical mixtures, allow for identification of unknowns (environmental diagnostics) for future chemical and biological methods development, and provide information on specific chemicals of concern that supports mitigation and management actions. Laboratory-based testing is well suited to identifying the range of biological activities and adverse health effects of specific chemicals and environmental chemical mixtures, defining the mechanisms of biological interaction across multiple modes of action, identifying exposure criteria for vulnerable species, and expanding the available bioassay toolbox. Use of fieldbased laboratories at long-term research sites provides unique laboratory control in a field-based setting. Continued use of high throughput testing of the biological activity of specific chemicals as well as more focused toxicological testing on a wide range of organisms are essential elements of the laboratory research component. Improved coordination among the three components of this integrated approach enables (1) feedback between field-based biological and chemical testing that results in detailed chemical characterization in environmental settings with documented biological activity and adverse health effects, (2) laboratory testing to identify the causes of toxicity in environmental chemical mixtures that are demonstrated to have biological consequences, and (3) improved, cost-efficient monitoring approaches that employ complementary use of bioassays and chemical analysis, and include high throughput testing of waters from demonstrated high-risk the pathways different chemicals take to the environment, the environmental persistence of chemicals and associated transformation products, the way chemicals interact biologically, and the associated risk of human and ecological exposure. This knowledge must be sufficient to prioritize and inform ecological and human risk assessments; support regulation and motivate voluntary actions to reduce the use of specific chemicals; improve chemical and waste handling, use, and disposal practices that mitigate environmental releases; and effectively upgrade wastewater and drinking-water treatment technologies. An integrated approach (fig. 8) simultaneously employing field-based biological (Environmental Biology) and chemical (Environmental Chemistry) testing along with systematic laboratory assessment of the effects of environmentally relevant chemicals and chemical mixtures (Laboratory Testing) offers a promising means of addressing these multiple environmental health objectives.

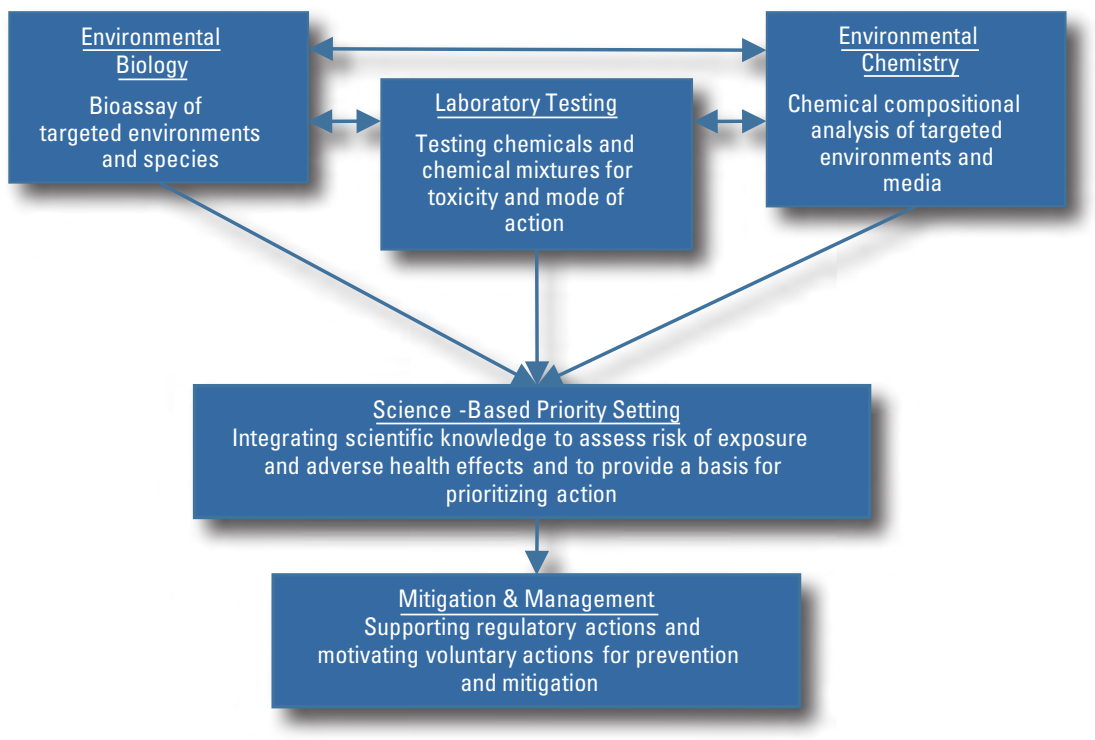

Figure 8. Diagram describing an approach to assessing environmental chemical mixtures that integrates field-based biological testing, field-based chemical testing, and systematic laboratory testing. 
environmental settings across the Nation. Furthermore, such an integrated approach enables efficient development of a robust scientific basis for prioritization of preventive and mitigating actions, support of regulatory action, and motivation of voluntary action by industry and the public.

\section{Federal Role}

The pilot study described herein is a collaborative effort that draws on the unique capabilities of the USGS and the EPA to

- Address a wide range of environmental settings across the Nation,

- Employ uniform field and laboratory protocols with extensive quality-assurance programs, and

- Apply the unprecedented scope of chemical and biological analytical capabilities available at USGS and EPA laboratories.

- Implement an integrated approach to assessing environmental chemical mixtures as described above.
Federal agency collaboration and coordination is essential for national-scale assessment of the potential adverse health effects of chemical mixtures in the environment; examples of recent field-based efforts are Glassmeyer and others (2005), Glassmeyer and others (2009), Beaver and others (2014), Cavallin and others (2014), and Barber and others (2015). The study described herein and subsequent national-scale, fieldbased efforts will support development of more cost-effective, environmentally representative, and scientifically defensible assessment approaches for chemical mixtures in a range of surface-water settings.

\section{Acknowledgments}

This interagency project was made possible by the cooperation of numerous scientists and technicians within the USGS and the EPA, including USGS field crews who collected samples at each stream site, USGS and EPA staff at the laboratories who processed and analyzed the samples, and the principal investigators who played a major role in designing and implementing the study (table 4).

Table 4. U.S. Geological Survey and U.S. Environmental Protection Agency principal investigators on the interagency project team.

\begin{tabular}{|c|c|}
\hline \multicolumn{2}{|c|}{ Principal Investigators } \\
\hline U.S. Geological Survey & U.S. Environmental Protection Agency \\
\hline Project Design and Coordination & Project Coordination \\
\hline Herbert T. Buxton & Su san T. Glassmeyer \\
\hline Dana W. Kolpin & Marc A. Mills (Chemistry) \\
\hline Kathryn M. Kuivila & Daniel L. Villeneuve (Bioassays) \\
\hline \multicolumn{2}{|l|}{ Timothy J. Reilly } \\
\hline Analytical Chemistry & Angela L. Batt \\
\hline Larry B. Barber & Mitchell Kostich \\
\hline William T. Foreman & Heath Mash \\
\hline Edward T. Furlong & Kathleen M. Schenck \\
\hline \multicolumn{2}{|l|}{ Michele L. Hladik } \\
\hline Keith A. Loftin & Bioassays \\
\hline Michael T. Meyer & Gerald T. Ankley \\
\hline \multirow[t]{2}{*}{ Kelly L. Smalling } & Adam D. Biales \\
\hline & Timothy W. Collette \\
\hline Bioassays & David M. DeMarini \\
\hline \multirow[t]{2}{*}{ Luke R. Iwanowicz } & Drew R. Ekman \\
\hline & Phillip C. Hartig \\
\hline Watershed and Chemical Data & David L. Lattier \\
\hline Kristin Romanok & James M. Lazorchak \\
\hline James L. Orlando & Jane Ellen Simmons \\
\hline \multirow{3}{*}{ Celeste Journey } & Mary Jean See \\
\hline & Quincy Teng \\
\hline & Vickie S. Wilson \\
\hline
\end{tabular}




\section{References Cited}

Aslop, D., and Wood, C.M., 2013, Metal and pharmaceutical mixtures-Is ion loss the mechanism underlying acute toxicity and widespread additive toxicity in zebrafish?: Aquatic Toxicology, v. 140-141, p. 257-267.

Baker-Austin, C., Wright, M.S., Stepanauskas, R., and McArthur, 2006, Co-selection of antibiotic and metal resistance: Trends in Microbiology, v. 14, no. 4, p. 176-182.

Barber, L.B., Loyo-Rosales, J.E., Rice, C.P., Minarik, T.A., and Oskouie, A.K., 2015, Endocrine disrupting alkylphenolic chemicals and other contaminants in wastewater treatment plant effluents, urban streams, and fish in the Great Lakes and upper Mississippi River regions: Science of the Total Environment, v. 517, p. 195-206.

Beaver, J.R., Manis, E.E., Loftin, K.A., Graham, J.L., Pollard, A.I., and Mitchell, R.M., 2014, Land use patterns, ecoregion, and microcystin relationships in U.S. lakes and reservoirs-A preliminary evaluation: Harmful Algae, v. 36, p. 57-62.

Belden, J.B., and Lydy, M.J., 2006, Joint toxicity of chlorpyrifos and esfenvalerate to fathead minnows and midge larvae: Environmental Toxicology and Chemistry: v. 25, no. 2, p. 623-629.

Boltes, K., Rosal. R., and Garcia-Calvo, E., 2012, Toxicity of mixtures of perfluorooctane sulphonic acid with chlorinated chemicals and lipid regulators: Chemosphere, v. 86, no. 1, p. 24-29.

Brian, J.V., Harris, C.A., Scholze, M., Kortenkamp, A., Booy, P., Lamoree, M., Pojana, G., Jonkers, N., Marcomini, A., and Sumpter, J.P., 2007, Evidence of estrogenic mixture effects on the reproductive performance of fish: Environmental Science and Technology, v. 41, no. 1, p. 337-344.

Bright, P.R., Buxton, H.T., Balistrieri, L.S., Barber, L.B., Chapelle, F.H., Cross, P.C., Krabbenhoft, D.P., Plumlee, G.S., Sleeman, J.M., Tillitt, D.E., Toccalino, P.L., and Winton, J.R., 2013, U.S. Geological Survey environmental health science strategy-Providing environmental health science for a changing world: U.S. Geological Survey Circular 1383-E, 43 p.

Carlin, D.J., Rider, C.V., Woychik, R., and Birnbaum, L.S., 2013, Unraveling the health effects of environmental mixtures-An NIEHS priority: Environmental Health Perspectives, v. 121, no. 1, p. A6-A8.
Cavallin, J.E., Durhan, E.J., Evans, N., Jensen, K.M., Kahl, M.D., Kolpin, D.W., Kolodziej, E.P., Foreman, W.T., Lalone, C.A., Makynen, E.A., Seidl, S.M., Thomas, L.M., Villeneuve, D.L., Weberg, M.A., Wilson, V.S., and Ankley, G.T., 2014, Integrated assessment of runoff from livestock farming operations-Analytical chemistry, in vitro bioassays, and in vivo fish exposures: Environmental Toxicology and Chemistry, v. 33, no. 8, p. 1849-1857.

Chen, C., Wang, Y., Qian, Y., Zhao, X., and Wang, Q., 2015, The synergistic toxicity of the multiple chemical mixturesImplications for risk assessment in the terrestrial environment: Environment International, v. 77, p. 95-105.

Christen, V., Crettaz, P., and Fent, K., 2014, Additive and synergistic antiandrogenic activities of mixtures of azol fungicides and vinclozolin: Toxicology and Applied Pharmacology, v. 279, no. 2, p. 169-176.

Cleuvers, M., 2004, Mixture toxicity of the anti-inflammatory drugs, diclofenac, ibuprofen, naproxen, and acetylsalicylic acid: Exotoxicology and Environmental Safety, v. 59, no. 3, p. 309-315.

Collins, F.S., Gray, G.M., and Bucher, J.R., 2008, Transforming environmental health protection: Science, v. 319 , no. 5865 , p. $906-907$.

Diamanti-Kandarakis, E., Bourguignon, J.P., Giudice, L.C., Hauser, R., Prins, G.S., Soto, A.M., Zoeller, R.T., and Gore, A.C., 2009, Endocrine-disrupting chemicals-An Endocrine Society Scientific Statement: Endocrine Reviews, v. 30, no. 4, p. 293-342.

Doyle, E., Biales, A., Focazio, M., Griffin, D., Loftin, K., and Wilson, V., 2015, Effect-based screening methods for water quality characterization will augment conventional analyte-by-analyte chemical methods in research as well as regulatory monitoring: Environmental Science and Technology, accessed May 29, 2015, at http://dx.doi.org/10.1021/ es5053254.

European Commission, 2015, Environment-Combination effects of chemicals, accessed January 7, 2015, at http:// ec.europa.eu/environment/chemicals/effects/effects_en.htm.

Fuhrman, V.F., Tal, A., and Arnon, S., 2015, Why endocrine disrupting chemicals (EDCs) challenge traditional risk assessment and how to respond: Journal of Hazardous Materials, v. 286, p. 589-611. 
Gaze, W.H., Abdousalam, N., Hawkey, P.M., and Wellington, E.M.H., 2005, Incidence of class 1 integrons in a quaternary ammonium compound-polluted environment: Antimicrobial Agents and Chemotherapy, v. 49, no. 5, p. 1802-1807.

Glassmeyer, S.T., Furlong, E.T., and Kolpin, D.W., 2009, Prevalence of emerging contaminants in drinking water across the United States: U.S. Environmental Protection Agency Science Brief, June 2009, 1 p.

Glassmeyer, S.T., Furlong, E.T., Kolpin, D.W., Cahill, J.D., Zaugg, S.D., Werner, S.L., Meyer, M.T., and Kryak, D.D., 2005, Transport of chemical and microbial compounds from known wastewater discharges-Potential for use as indicators of human fecal contamination: Environmental Science and Technology, v. 39, no. 14, p. 5157-5169.

Gonzalez-Pleiter, M., Gonzalo, S., Rodea-Palomares, I., Leganes, F., Rosal, R., Boltes, K., Marco, E., and Fernandez-Pinas, F., 2013, Toxicity of five antibiotics and their mixtures towards photosynthetic aquatic organisms: Implications for environmental risk assessment: Water Research, v. 47, p. 2050-2064.

Hadrup, N., 2014, Evidence from pharmacology and pathophysiology suggests that chemicals with dissimilar mechanisms of action could be of bigger concern in the toxicological risk assessment of chemical mixtures than chemicals with a similar mechanism of action: Regulatory Toxicology and Pharmacology, v. 69, no. 3, p. 281-283.

Hladik, M.L., Orlando J.L., and Kuivila, K.M., 2009, Collection of pyrethroids in water and sediment matrices: development and validation of a standard operating procedure: U.S. Geological Survey Scientific Investigations Report 2009-5012, 22 p. [Also available at http://pubs.usgs.gov/ $\operatorname{sir} / 2009 / 5012 /$.

Kane, G.C., and Lipsky, J.J., 2000, Drug-grapefruit juice interactions: Mayo Clinic Proceedings, v. 75, p. 933-942.

Kidd, K.A., Blanchfield, P.J., Mills, K.H., Palace, V.P., Evans, R.E., Lazorchak, J.M., and Flick, R.W., 2007, Collapse of a fish population after exposure to a synthetic estrogen: Proceedings of the National Academy of Sciences, U.S.A., v. 104, no. 21, p. 8897-8901.

Kortenkamp, A., 2014, Low dose mixture effects of endocrine disrupters and their implications for regulatory thresholds in chemical risk assessment: Current Opinion in Pharmacology, v. 19, p. 105-111.

Kummerer, K., 2009, Antibiotics in the aquatic environmentA review-Part I: Chemosphere, v. 75, no. 4, p. 417-434.
Kurenbach, B., Marjoshi, D., Amabile-Cuevas, C.F., Ferguson, G.C., Godsoe, W., Gibson, P., and Heinemann, J.A., 2015, Sublethal exposure to commercial formulations of the herbicides dicamba, 2,4-dichlorophenoxyacetic acid, and glyphosate cause changes in antibiotic susceptibility in Escherichia coli and Salmonella enterica serovar Typhimurium: mBio, v. 6 , no. 2, p. 1-9.

Laetz, C.A., Baldwin, D.H., Collier, T.K., Hebert, V., Stark, J.D., and Scholz, N.L., 2009, The synergistic toxicity of pesticide mixtures - Implications for risk assessment and the conservation of endangered pacific salmon: Environmental Health Perspectives, v. 117, no. 3, p. 348-353.

Lokke, H., Ragas, A.M.J., and Holmstrup, M., 2013, Tools and perspectives for assessing chemical mixtures and multiple stressors: Toxicology, v. 313, no. 2-3, p. 73-82.

Martinez, J.L., 2014, General principles of antibiotic resistance in bacteria: Drug Discovery Today_-Technologies, v. 11, p. 33-39.

National Research Council, 2007, Toxicity testing in the 21 st century-A vision and a strategy: Washington, D.C., National Academies Press, 196 p.

Norwood, W.P., Borgmann, U., Dixon, D.G., and Wallace A., 2003, Effects of metal mixtures on aquatic biota-A review of observations and methods: Human and Ecological Risk Assessment, v. 9, no. 4, p. 795-811.

Orton, F., Ermler, S., Kugathas, S., Rosivatz, E., Scholze, M., and Kortenkamp, A., 2014, Mixture effects at very low doses with combinations of anti-androgenic pesticides, antioxidants, industrial pollutant and chemicals used in personal care products: Toxicology and Applied Pharmacology, v. 278 , no. 3 , p. 201-208.

Pomati, F., Orlandi, C., Clerici, M., Luciani, F., and Zuccato, E., 2008, Effects and interactions in an environmentally relevant mixture of pharmaceuticals: Toxicological Sciences, v. 102, no. 1, p. 129-137.

Sanchez, P., Moreno, E., and Martinez, J.L., 2005, The biocide triclosan selects Stenotrophomonas maltophilia mutants that overproduce the SmeDEF multidrug efflux pump: Antimicrobial Agents and Chemotherapy, v. 49 no. 2, p. 781-782.

Schneider, K., Roller, M., Kalberlah, F., and SchuhmacherWolz, U., 2002, Cancer risk assessment for oral exposure to PAH mixtures: Journal of Applied Toxicology, v. 22, no. 1, p. $73-83$. 
Schnell, S., Bols, N.C., Barata, C., and Porte, C., 2009, Single and combined toxicity of pharmaceuticals and personal care products (PPCPs) on the rainbow trout liver cell line RTLW1: Aquatic Toxicology, v. 93, no, 4, p. 244-252.

Sexton, K., and Hattis, D., 2007, Assessing cumulative health risks from exposure to environmental mixtures-Three fundamental questions: Environmental Health Perspectives, v. 115 , no. 5 , p. $825-832$.

Shelton, L.R., 1994, Field guide for collecting and processing stream-water samples for the National Water-Quality Assessment Program: U.S. Geological Survey Open-File Report 94-455, 50 p. [Also available at http://pubs.er.usgs. gov/publication/ofr94455.]

Smith, K.E.C., Schmidt, S.N., Dom, N., Blust, R., Holmstrup, M., and Mayer, P., 2013, Baseline toxic mixtures of nontoxic chemicals- "Solubility addition" increases exposure for solid hydrophobic chemicals: Environmental Science and Technology, v. 47, no. 4, p. 2026-2033.

Tang. J.Y.M., Busetti, F., Charrois, J.W.A., and Escher, B.I., 2014, Which chemicals drive biological effects in wastewater and recycled water?: Water Research, v. 60, p. 289-299.

U.S. Environmental Protection Agency, 2015, ToxCast ${ }^{\mathrm{TM}}$ Advancing the next generation of chemical safety evaluation, accessed May 26, 2015, at http://www.epa.gov/ ncct/toxcast/.
Wang, P., Luo, L., Ke, L., Luan, T., and Tam, N.F., 2013, Combined toxicity of polycyclic aromatic hydrocarbons and heavy metals to biochemical and antioxidant responses of free and immobilized Selenastrum capricornutum: Environmental Toxicology and Chemistry, v. 32, no. 3, p. 673-683.

Wellington, E.M.H., Boxall, A.B.A, Cross, P., Feil, E.J., Gaze, W.H., Hawkey, P.M., Johnson-Rollings, A.S., Jones, D.L., Lee, N.M., Otten, W., Thomas, C.M., and Williams, A.P., 2013, The role of the natural environment in the emergence of antibiotic resistance in Gram-negative bacteria: The Lancet Infectious Diseases, v. 13, no. 2, p. 155-165.

Wilde, F.D., ed., 2004a, Cleaning of equipment for water sampling (ver. 2.0): U.S. Geological Survey Techniques of Water-Resources Investigations, book 9, chap. A3, April 2004, available at http://pubs.water.usgs.gov/twri9A3/.

Wilde, F.D., Radtke, D.B., Gibs, Jacob, and Iwatsubo, R.T., eds., 2004b with updates through 2009, Processing of water samples (ver. 2.2): U.S. Geological Survey Techniques of Water-Resources Investigations, book 9, chap. A5, April 2004, available at http://pubs.water.usgs.gov/twri9A5/.

World Health Organization, 2015, Assessment of combined exposures to multiple chemicals: International Programme on Chemical Safety, accessed January 7, 2015, at http://www.who.int/ipcs/methods/harmonization/areas/ aggregate/en/.

\section{For Additional Information}

Online:

USGS Environmental Health science www.usgs.gov/envirohealth/

USGS Research on Toxic Substances in the environment toxics.usgs.gov

USGS Research on environmental chemical mixtures toxics.usgs.gov/chemmix
Contacts:

Coordinator, Toxic Substances

Hydrology Program,

Michael Focaziomfocazio@usgs.gov

Chemical Mixtures Team Leader,

Paul Bradley pbradley@usgs.gov 